\title{
Taxonomic Implications of Seed Morphology and Seed Protein Electrophoresis of Some Egyptian Taxa of the Mimosoideae-Leguminosae.
}

\author{
N.M. George, H.A. Hussein, A. Ghareeb and M.M. El- \\ Demerdash \\ Botany Department, Faculty of Science, Zagazig University, Egypt
}

\begin{abstract}
7 HE SEED macro-morphological features including seed shape, colour, size, areole shape as well as the testa sculpturing patterns examined by scanning electron microscopy (SEM) and SDSPAGE profiles of seed proteins of 14 species and one subspecies; representing eight genera of Mimosoideae were investigated. A key to the taxa studied was provided based on the recorded macromorphological features and the testa sculpturing patterns as viewed under SEM. The phenogram generated from the numerical analysis of the scored characters from SDS-PAGE profiles of seed proteins was beneficial to discuss some of the fore-mentioned opinions concerning the taxonomic status of members of Mimosoideae.
\end{abstract}

Keywords: Mimosoideae; SEM; Seed Morphology; Testa Sculpture; SDS-PAGE

Mimosoideae is one of the three widely recognized subfamilies of Leguminosae (Elias, 1981). The Mimosoideae (treated as family Mimosaceae by Hutchinson, 1964) comprises 82 genera and 3335 species distributed throughout tropical and warm temperate regions of the world (Stevens, 2001). Mimosoideae is represented in the Egyptian flora by 5 genera, 10 species, 4 subspecies and two varieties (Boulos, 1999).

Bentham (1875), in his revision, established six tribes namely; Acacieae, Adenanthereae, Eumimoseae, Ingeae, Parkieae and Piptadenieae containing 46 genera of the Mimosoideae. Later on, Bentham's classification of Mimosoideae into tribes had been subjected to some modifications by Burkart (1939), Hutchinson (1964) and Lewis \& Elias (1981). Furthermore, Elias (1981) distinguished between the following five tribes: Acacieae, Ingeae, Mimoseae, Mimozygantheae and Parkieae as constituents of the Mimosoideae depending upon the following characters: calyx either imbricate or valvate in bud; sepals either joined or free; stamens more than 10 or either 10 or fewer free or joined.

The use of SEM in studying the morphology of seeds has revealed new finer details on their surface which, in turn, yielded valuable taxonomic information adopted in solving many taxonomic problems (Chaung \& Heckard, 1983; Hussein et al., 2002 a, b; Abou-El-Enain et al., 2007 and Gunes, 2012). 
Morphology of seeds of many mimosoid taxa has been treated variously in many studies among them: Manning \& Van Staden (1987), Al-Gohary \& Mohamed (2007) and Karakish et al. (2013). Electrophoresis has become an additional tool applied in resolving taxonomic and phylogenetic problems (George et al., 2013 and Burghardt \& Espert, 2007). Most applications of electrophoretic techniques in plant classifications use gel medium supports. This has resulted from the reliability of data produced by gel electrophoresis, which have been accepted widely, particularly in studies of plant population genetics (Omonhinmin \& Ogunbodede, 2013 and Atoyebi et al., 2014). The use of seed protein electrophoretic profiles in addressing taxonomic relationships among some Leguminosae taxa has been highlighted by many researchers namely: Badr (1995); Ghareeb et al. (1999) and Arslan \& Ertugrul (2010). Thus, the present study aims to characterize the seed morphological features including the testa

sculpturing patterns as viewed under SEM and to evaluate the genetic diversity and taxonomic relationships among 12 species and 3 subspecies of Egyptian Mimosoideae using SDS-PAGE analysis of seed storage proteins. The main objective of this study is to collect additional criteria which can be of more taxonomic interest in delimitation and differentiation among the taxa studied.

\section{Material and Methods}

\section{Material}

Specimens containing mature dry pods of 14 species and one subspecies of Mimosoideae were collected from June, 2001 to August 2004. Some of them were gained only as mature dry pods (Table 1). The collected specimens include both wild and horticultural ones. The identification of both of them was achieved by the morphological comparison against authentic herbarium specimens kept at the herbarium of Orman Botanical Garden, Giza, Egypt. The scientific names, synonyms and the author citations were rechecked and updated according the website: www.theplantlist.org.

\section{Methods \\ A. Seed Morphological Features}

The seed dimensions; length (L) and breadth (B) of each specimen, were measured as average of 10 seeds by using the vernier caliper. The general macromorphological features of the seeds; including the shape, colour and the areole shape were directly recorded from the specimens examined. For SEM-observations of the testa surface patterns, at least two seeds for each specimen were mounted on stubs, coated with a thin layer of gold and examined at different positions using JEOL-JSM-5400 scanning electron microscope at Electron Microscope Unit, Assiut University since 2003-2004. The characters were recorded and SEMmicrographs, exhibiting the testa sculpturing were taken towards the mid-seed involving the pleurogram and part of the areole with a range of magnification between (500x-1500x). The terminology listed by Stearn (1983) and also that of Lersten (1981), with some modifications by the authors, were adopted for 
description of the seed surface sculpturing patterns. In addition, Polhill et al. (1981) defined that the hard seeds of Mimosoideae generally have an area on each face (the areole) bounded by a crack in the testa (the pleurogram). Gunn (1981) added that the fracture lines, on the seed surface, are cracks formed during seed maturation and appear to be in the thick cuticle layer.

TABLE 1. The collection data with their sources of collection.

\begin{tabular}{|c|c|c|}
\hline No. & Taxa & Source of collection in Egypt \\
\hline 1. & $\begin{array}{l}\text { Acacia saligna (Labill.) Wendl. } \\
\text { (=Acacia cyanophylla Lindl.) }\end{array}$ & Parks at Zagazig Univ., Zagazig. \\
\hline 2. & Acacia farnesiana (L.) Willd. ${ }^{(*)}$ & Canal banks, Beni Swif. \\
\hline 3. & $\begin{array}{l}\text { Acacia nilotica }(\text { L.) Delile } \\
\text { (=Acacia nilotica }(\text { L.) Delile subsp. } \\
\text { nilotica })\end{array}$ & Canal banks, Zagazig. \\
\hline 4. & $\begin{array}{l}\text { Acacia tortilis (Forssk.) Hayne }{ }^{(*)} \\
\text { (=Acacia tortilis (Forssk.) Hayne subsp. tortilis) }\end{array}$ & El Tur, South Sinai. \\
\hline 5. & $\begin{array}{l}\text { Acacia tortilis (Forssk.) Hayne subsp. } \\
\text { raddiana (Savi) Brenan }{ }^{(*)}\end{array}$ & El Tur, South Sinai. \\
\hline 6. & Albizia julibrissin Durazz. & Orman Botanical Garden, Giza. \\
\hline 7. & Albizia lebbeck (L.) Benth. & Salah Salem road, Cairo. \\
\hline 8. & Dichrostachys cinerea (L.) Wight \& Arn. & Orman Botanical Garden, Giza. \\
\hline 9. & $\begin{array}{l}\text { Enterolobium contortisiliquum (Vell.) } \\
\text { Morong }\end{array}$ & The Zoo, Giza. \\
\hline 10. & $\begin{array}{l}\text { Enterolobium cyclocarpum (Jacq.) } \\
\text { Griseb. }\end{array}$ & The Zoo, Giza. \\
\hline 11. & $\begin{array}{l}\text { Faidherbia albida (Delile) A. Chev. } \\
\text { (= Acacia albida Delile) }\end{array}$ & Agricultural Museum, Giza. \\
\hline 12 & $\begin{array}{l}\text { Leucaena leucocephala (Lam.) de Wit } \\
\text { (=Leucaena glauca (L.) Benth.) }\end{array}$ & The Zoo, Giza \\
\hline 13. & $\begin{array}{l}\text { Pithecellobium dulce (Roxb.) Benth. } \\
\text { (=Inga dulcis (Roxb.) Willd.) }\end{array}$ & The Zoo, Giza. \\
\hline 14. & Prosopis farcta (Banks \& Sol.) Macbr. ${ }^{\left({ }^{* *}\right)}$ & Bahariya Oasis. \\
\hline 15. & Prosopis juliflora (Sw.) DC. & The Zoo, Giza. \\
\hline & \multicolumn{2}{|c|}{$\begin{array}{l}\text { Specimens collected from the herbarium of Cairo University. } \\
\text { Specimen collected from herbarium of Orman Botanical Garden. }\end{array}$} \\
\hline
\end{tabular}

\section{B. Seed protein electrophoresis}

Total protein from $0.2 \mathrm{gm}$ of milled seeds, of each of the collected specimens, were extracted overnight using $0.2 \mathrm{M}$ Tris- $\mathrm{HCl}$ buffer, $\mathrm{PH} 6.8$ containing $2 \%$ SDS and $10 \%$ glycerol. Centrifugation was carried out at 9000 rpm for 6 min. Then $30 \mu \mathrm{l}$ supernatant were loaded in $12.5 \%$ acrylamide slab gels containing $10 \%$ SDS. Run power was $15 \mathrm{~mA}$ for about $30 \mathrm{~min}$. Then raised up to $25 \mathrm{~mA}$ for 6-7 hr. The molecular weights of separated protein bands were compared with standards protein ladder ranging from 27 to $116 \mathrm{KDa}$. Gel was then stained in Comassie blue for $16 \mathrm{hr}$ at room temperature, destained and photographed. The bands produced by each sample were directly scored as 0 for absent and 1 for present bands. 
The data were treated by numerical analysis using the program NTSYS-pc. (Rholf, 1988). The similarity between each two taxa; based on comparisons of their SDS-PAGE profiles, was calculated using Jaccard's coefficient of similarity.

\section{Results and Discussion}

\section{A. Seed Morphological Features}

Variation in macro-morphological features of the seed including seed shape, colour, size and the areole shape as well as the testa sculpturing patterns as seen by SEM were outlined in Table 2. In addition, the testa surface, in the taxa studied, as viewed under SEM exhibited the pleurogram as a break in the testa surrounding the areole. Cracks or fracture lines were, also, commonly observed at different parts of the seed especially near the hilum or towards the mid-seed (Fig. 1A-Q).

The seed was either compressed (11 taxa) or not compressed in Acacia farnesiana, Enterolobium contortisiliquum, E. cyclocarpum and Prosopis juliflora. The shape of seed was oval, broad oval, oval-oblong or oblong. The colour of seed varied from pale brown to glossy dark brown and only brown mottled with yellowish white streaks and spots in Acacia nilotica. The mean length of seeds ranged from $4.9 \mathrm{~mm}$ to $11.9 \mathrm{~mm}$. The smallest seeds were recorded in Acacia saligna and Dichrostachys cinerea whereas seeds of Enterolobium cyclocarpum are the longest ones. The areole shape was linear oblong in Acacia saligna, oblong in Albizia julibrissin and A. lebbeck, ovaloblong in Acacia tortilis, Enterolobium contortisiliquum and E. cyclocarpum; broad oval in Acacia nilotica and Dichrostachys cinerea and oval in the remaining seven taxa (Table 2). The testa sculpturing patterns observed under SEM were clearly variable among the taxa investigated (Table 2 and Fig. 1A-Q).

The seed morphological characteristics such as shape, colour, size and areole shape; if present, in combination with the testa sculpturing peculiarities observed under SEM had been found very useful in delimitation and identification of genera and species within family Leguminosae (Hussein et al., 2002 a, b; Taia, 2004; Abou-El-Enain et al., 2007 and Al-Gohary \& Mohamed, 2007). Hussein et al. (2012) stated that diversity in the characteristics of the micropyle, hilum, and lens of seeds of Mimosoideae, when observed under SEM, offer indispensable criteria for separation primarily at the species level and sometimes at the subspecies level as well as very rarely at the rank of genus. In this work, the seed shape seems to be a reliable criterion for separating some of the taxa at the species level. Albizia lebbeck with compressed oval-oblong seeds could be distinguished from A. julibrissin with compressed oblong seeds. Prosopis farcta with compressed oval seeds could be differentiated from Prosopis juliflora with oval seeds. Also, the seed shape may represent a useful character for separation of Acacia tortilis subsp. raddiana with compressed broad oval seeds from $A$. tortilis having compressed oval seeds. However, Enterolobium contortisiliquum and E. cyclocarpum retained a similar seed shape which is oval-oblong. The seed

Egypt. J. Bot., Vol. 56, No. 1 (2016) 
colour appeared clearly distinctive to Acacia nilotica; where it is brown mottled with yellowish white streaks and spots. Gunn (1981) reported that the legume testa is usually monochrome brown to black, rarely red, cream or white or occasionally dichrome as mottling or two distinct coloured areas.

TABLE 2. The macro- and micro-morphological features of seeds of the studied Mimosoideae taxa.

\begin{tabular}{|c|c|c|c|c|c|c|c|c|}
\hline \multirow{2}{*}{$\begin{array}{l}\text { Characters } \\
\text { Taxa }\end{array}$} & \multirow{2}{*}{$\begin{array}{c}\text { Seed } \\
\text { Comp }^{\circ}\end{array}$} & \multirow{2}{*}{ Shape } & \multirow{2}{*}{ Colour } & \multicolumn{3}{|c|}{$\operatorname{Size}(* *) \mathbf{m m}$} & \multirow{2}{*}{ Areole } & \multirow{2}{*}{ Surface Pattern } \\
\hline & & & & $\mathbf{L}$ & B & Grade & & \\
\hline Acacia saligna & + & $\begin{array}{l}\text { oval- } \\
\text { oblong }\end{array}$ & $\begin{array}{l}\text { glossy } \\
\text { dark } \\
\text { brown } \\
\end{array}$ & 4.9 & 2.4 & (S) & $\begin{array}{c}\text { linear } \\
\text { oblong }\end{array}$ & $\begin{array}{c}\text { faint irregularly } \\
\text { tuberculate (Fig. } \\
\text { 1A\&B) }\end{array}$ \\
\hline Acacia farnesiana & - & oval & brown & 7.2 & 5.1 & (M) & oval & $\begin{array}{c}\text { irregularly } \\
\text { regulate (Fig. } \\
1 \mathrm{C})\end{array}$ \\
\hline Acacia nilotica & + & $\begin{array}{l}\text { broad } \\
\text { oval }\end{array}$ & brown $^{(*)}$ & 7.8 & 5.7 & (M) & $\begin{array}{c}\text { broad } \\
\text { oval }\end{array}$ & $\begin{array}{l}\text { compact } \\
\text { regulate (Fig. } \\
\text { 1D) }\end{array}$ \\
\hline Acacia tortilis & + & oval & brown & 5.3 & 3.6 & (M) & $\begin{array}{c}\text { oval- } \\
\text { oblong }\end{array}$ & $\begin{array}{c}\text { ill-defined } \\
\text { coupled with } \\
\text { some variable } \\
\text { pits (Fig. 1F) }\end{array}$ \\
\hline $\begin{array}{l}\text { Acacia tortilis subsp. } \\
\text { raddiana }\end{array}$ & + & $\begin{array}{l}\text { broad } \\
\text { oval }\end{array}$ & brown & 6.4 & 4.7 & (M) & oval & $\begin{array}{l}\text { ill-defined } \\
\text { coupled with } \\
\text { some variable } \\
\text { pits (Fig. 1E) }\end{array}$ \\
\hline Albizia julibrissin & + & oblong & brown & 8.6 & 4.2 & (M) & oblong & $\begin{array}{c}\text { irregularly } \\
\text { foveolate with } \\
\text { variable } \\
\text { foveolae (Fig. } \\
1 \mathrm{G})\end{array}$ \\
\hline Albizia lebbeck & + & $\begin{array}{l}\text { oval- } \\
\text { oblong }\end{array}$ & $\begin{array}{c}\text { pale } \\
\text { brown }\end{array}$ & 10.8 & 7.6 & (L) & oblong & $\begin{array}{l}\text { compact coarse } \\
\text { rugulate } \\
\text { frequently with } \\
\text { exaggerated } \\
\text { thick rugae } \\
\text { coupled with } \\
\text { sparsely } \\
\text { scattered } \\
\text { variable pits } \\
\text { (Fig. } 1 \mathrm{H} \text { ) } \\
\end{array}$ \\
\hline $\begin{array}{l}\text { Dichrostachys } \\
\text { cinerea }\end{array}$ & + & $\begin{array}{l}\text { broad } \\
\text { oval }\end{array}$ & $\begin{array}{l}\text { glossy } \\
\text { brown }\end{array}$ & 4.9 & 3.7 & $(\mathrm{~S})$ & $\begin{array}{c}\text { broad } \\
\text { oval }\end{array}$ & $\begin{array}{l}\text { inconspicuous } \\
\text { rugulate to ill- } \\
\text { defined coupled } \\
\text { with variable } \\
\text { pits (Fig. 1I) }\end{array}$ \\
\hline
\end{tabular}


TABLE 2 Cont. The macro- and micro-morphological features of seeds of the studied Mimosoideae taxa.

\begin{tabular}{|c|c|c|c|c|c|c|c|c|}
\hline \multirow{2}{*}{$\begin{array}{c}\text { Characters } \\
\text { Taxa }\end{array}$} & \multirow{2}{*}{\begin{tabular}{|c} 
Seed \\
Comp
\end{tabular}} & \multirow{2}{*}{ Shape } & \multirow{2}{*}{ Colour } & \multicolumn{3}{|c|}{$\operatorname{Size}(* *) \mathbf{m m}$} & \multirow{2}{*}{ Areole } & \multirow{2}{*}{ Surface Pattern } \\
\hline & & & & $\mathbf{L}$ & B & Grade & & \\
\hline $\begin{array}{l}\text { Enterolobium } \\
\text { contortisiliquum }\end{array}$ & - & $\begin{array}{l}\text { oval- } \\
\text { oblong }\end{array}$ & $\begin{array}{l}\text { dark } \\
\text { brown }\end{array}$ & 9.1 & 3.7 & (M) & $\begin{array}{c}\text { oval- } \\
\text { oblong }\end{array}$ & $\begin{array}{c}\text { irregularly } \\
\text { reticulate- } \\
\text { foveolate with } \\
\text { thick anticlinal } \\
\text { ridges (Fig. } 1 \mathrm{~J} \text { ) }\end{array}$ \\
\hline $\begin{array}{l}\text { Enterolobium } \\
\text { cyclocarpum }\end{array}$ & - & $\begin{array}{l}\text { oval- } \\
\text { oblong }\end{array}$ & $\begin{array}{l}\text { dark } \\
\text { brown }\end{array}$ & 11.9 & 6.9 & (L) & $\begin{array}{c}\text { oval- } \\
\text { oblong }\end{array}$ & $\begin{array}{c}\text { irregularly } \\
\text { papillose (Fig. } \\
1 \mathrm{~K})\end{array}$ \\
\hline Faidherbia albida & + & oval & $\begin{array}{l}\text { glossy } \\
\text { brown }\end{array}$ & 7.8 & 4.6 & (M) & oval & $\begin{array}{c}\text { obsoletely } \\
\text { tuberculate(Fig. } \\
\text { 1L) }\end{array}$ \\
\hline $\begin{array}{l}\text { Leucaena } \\
\text { leucocephala }\end{array}$ & + & oval & $\begin{array}{l}\text { glossy } \\
\text { brown }\end{array}$ & 6.9 & 4.6 & (M) & oval & $\begin{array}{l}\text { faint polygonal- } \\
\text { discoid plates } \\
\text { covered with } \\
\text { micro-striations } \\
\text { (Fig. } 1 \mathrm{N \& O} \text { ) }\end{array}$ \\
\hline Pithecellobium dulce & + & $\begin{array}{l}\text { broad } \\
\text { oval }\end{array}$ & $\begin{array}{c}\text { dark } \\
\text { brown- } \\
\text { black }\end{array}$ & 10.8 & 8.8 & (L) & oval & $\begin{array}{c}\text { prominent } \\
\text { irregularly } \\
\text { tuberculate (Fig. } \\
1 \mathrm{M})\end{array}$ \\
\hline Prosopis farcta & + & oval & brown & 8.1 & 5.1 & (M) & oval & $\begin{array}{l}\text { irregularly } \\
\text { reticulate- } \\
\text { foveolate to ill- } \\
\text { defined with } \\
\text { ridges of the } \\
\text { reticulae thick } \\
\text { and micro- } \\
\text { striated (Fig. 1P) }\end{array}$ \\
\hline Prosopis juliflora & - & oval & $\begin{array}{l}\text { glossy } \\
\text { pale } \\
\text { brown }\end{array}$ & 5.2 & 3.8 & (M) & oval & $\begin{array}{l}\text { compact fine } \\
\text { rugulate coupled } \\
\text { with sparsely } \\
\text { scattered } \\
\text { variable pits } \\
\text { (Fig. 1Q) }\end{array}$ \\
\hline
\end{tabular}

${ }^{+}$Seed compressed; - Seed not compressed; L=Length; B= Breadth; Brown $(*)=$ Brown mottled with yellowish white streaks and spots; Comp ${ }^{\bullet}=$ Seed compression; $\left({ }^{* *}\right)$ Concerning seed size the following grades were taken into consideration: Small-sized seeds (S) i.e. less than $5 \mathrm{~mm}$ long; Medium-sized seeds (M) i.e. 5-10 mm long; Largesized seeds (L) i.e. More than $10 \mathrm{~mm}$ long. 

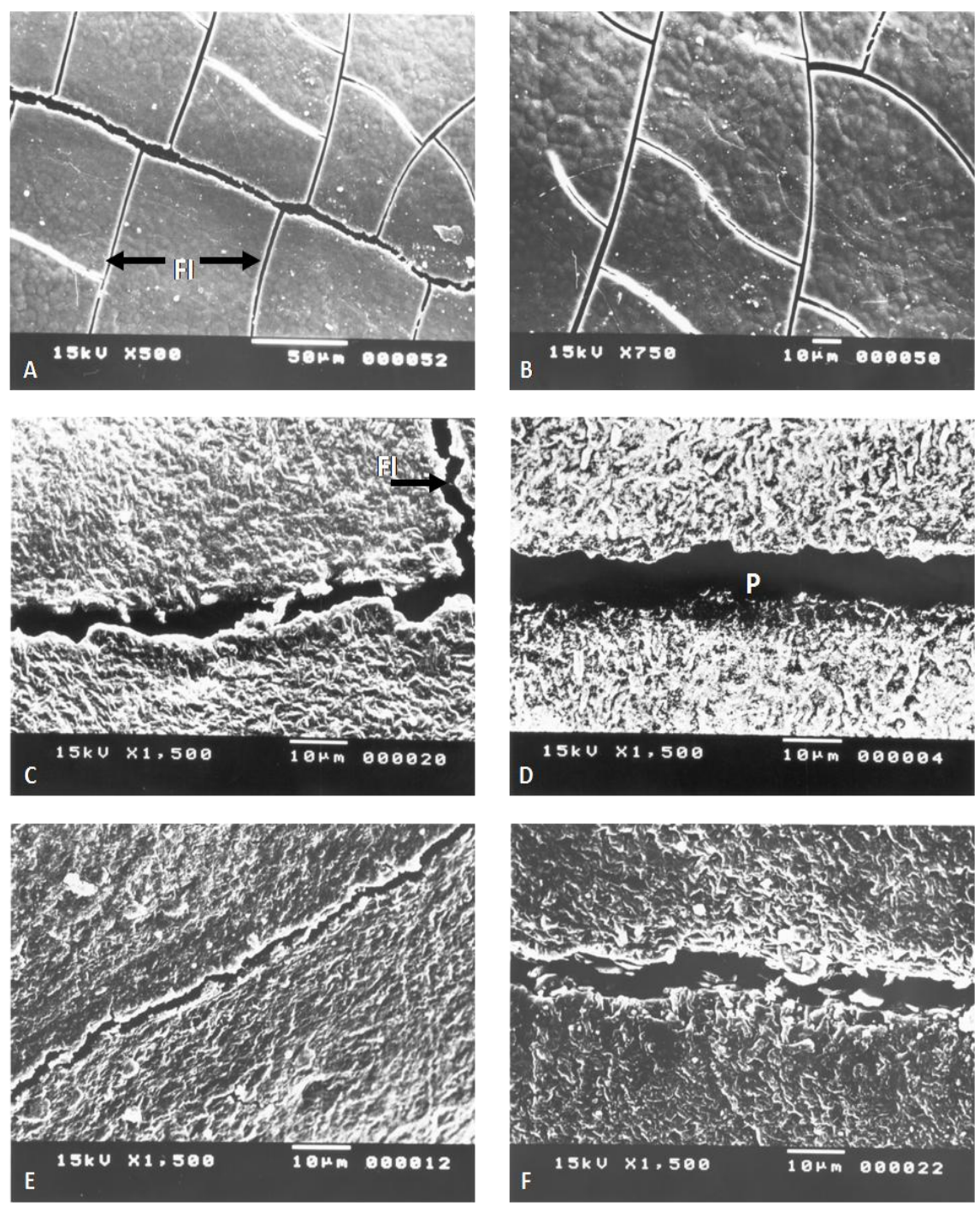

Fig 1 (A-F). SEM-Photomicrographs showing variation in the testa sculpturing patterns. A\&B. Acacia saligna, $\mathrm{x}=\mathbf{5 0 0}, \mathbf{7 5 0}$, respectively; C. Acacia farnesiana, $\mathrm{x}=1500$; D. Acacia nilotica, $\mathrm{x}=1500$; E. Acacia tortilis subsp. raddiana, $\mathrm{x}=1500 ; \mathrm{F}$. Acacia tortilis, $\mathrm{x}=1500 ; \mathrm{Fl}=$ Fracture lines; $\mathbf{P}=$ Pleurogram. 

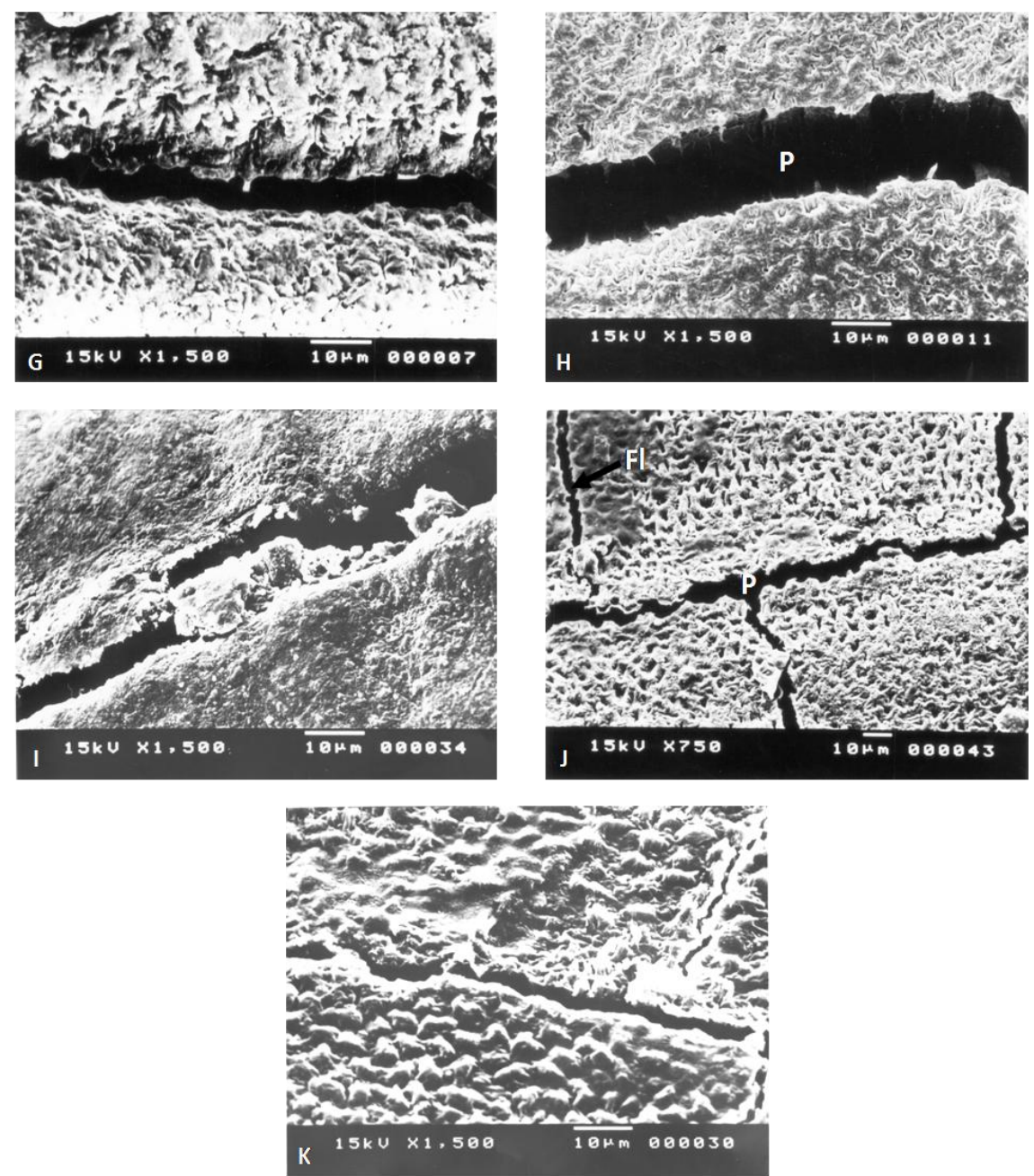

Fig. 1. "continued" (G-K): SEM-Photomicrographs showing variation in the testa sculpturing patterns. G. Albizia julibrissin, $\mathrm{x}=1500$; H. Albizia. lebbeck, $\mathrm{x}=$ 1500; I. Dichrostachys cinerea, $x=1500$; J. Enterolobium contortisiliquum, $x=$ 750; K. Enterolobium cyclocarpum, $\mathrm{x}=1500 ; \mathrm{Fl}=$ Fracture lines; $\mathrm{P}=$ Pleurogram. 

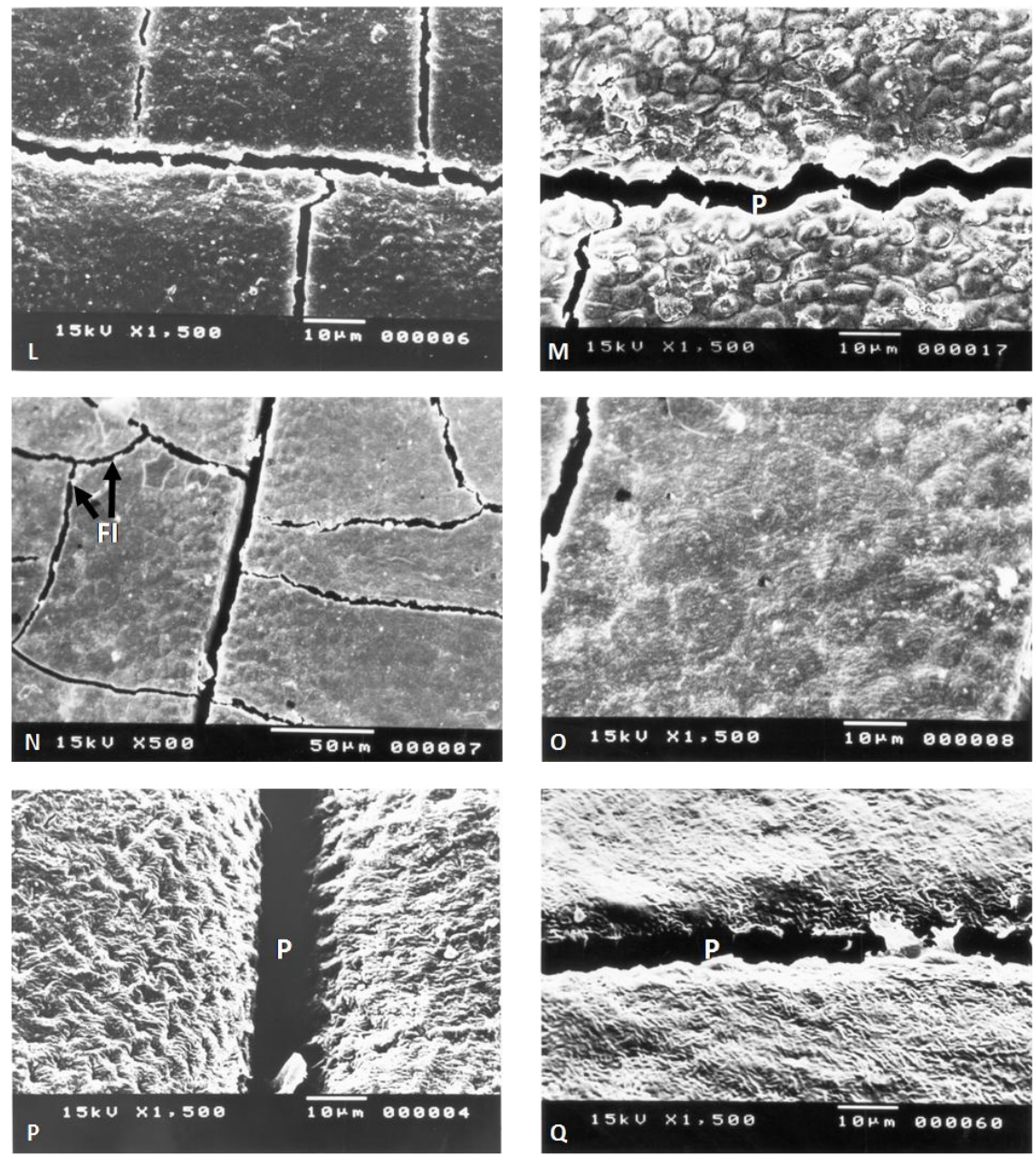

Fig. 1. "continued" (L-Q): SEM-Photomicrographs showing variation in the testa sculpturing patterns. L. Faidherbia albida, $x=1500$; M. Pithecellobium dulce, $\mathrm{x}=1500 ; \quad \mathrm{N} \& 0$. Leucaena leucocephala, $\mathrm{x}=500,1500$, respectively; $P$. Prosopis farcta, $\mathrm{x}=1500 ; \mathrm{Q}$. Prosopis juliflora, $\mathrm{x}=1500 ; \mathrm{Fl}=$ Fracture lines; $\mathrm{P}$

The testa surface, among the taxa studied, exhibited seven basic sculpturing patterns namely: regulate, reticulate-foveolate, foveolate, faint polygonal-discoid plates, tuberculate, papillose and ill-defined coupled with variable pits. Furthermore, intergraded forms within some of the basic patterns were also observed. Manning and Van Staden (1987) reported the common occurrence of cuticular sculpturing in seeds of Mimosoideae which is usually rugose but sometimes it also exhibits modifications. Furthermore, Lersten \& Gunn (1982) stated that the papillose pattern of the testa in many members of Leguminosae results from the protrusion of the tips of the epidermal cells. 
The variation in the testa sculpturing patterns has been found very useful in the differentiation of the taxa studied The combination of the salient macromorphological features with the testa surface sculpturing patterns have ascertained the differentiation and segregation of the taxa investigated as illustrated in the following key:

\section{Seeds compressed}

A. Seeds oval-oblong or oblong

B1. Testa faint irregularly tuberculate.....................Acacia saligna

B2. Testa irregularly foveolate with variable foveolae.........Albizia julibrissin

B3. Testa compact coarse rugulate frequently with exaggerated thick rugae coupled with sparsely scattered variable pits. Albizia lebbeck

AA. Seeds oval or broad ova

C1. Testa ill-defined coupled with some variable pits; seeds brown

D1. Areole oval... Acacia tortilis subsp. raddiana

D2. Areole oval-oblong Acacia tortilis

C2. Testa compact regulate; seeds brown mottled with yellowish white streaks and spots Acacia nilotica

C3. Testa inconspicuous rugulate to ill-defined coupled with variable pits; seeds glossy brown .................Dichrostachys cinerea

C4. Testa tuberculate

E1. Testa obsoletely tuberculate; seeds glossy brown ........Faidherbia albida

E2.Testa prominent irregularly tuberculate; seeds dark brown-black Pithecellobium dulce

C5. Testa with faint polygonal-discoid plates covered with micro-striations Leucaena leucocephala

C6. Testa irregularly reticulate-foveolate to ill-defined with ridges of the reticulae thick and micro-striated Prosopis farcta

II. Seeds not compressed

F1. Seeds oval

G1. Testa irregularly regulate. Acacia farnesiana

G2. Testa compact fine rugulate coupled with sparsely scattered variable pits Prosopis juliflora

F2. Seeds oval-oblong

H1. Testa irregularly reticulate-foveolate with thick anticlinal ridges ....................Enterolobium contortisiliquum

H2. Testa irregularly papillose. Enterolobium cyclocarpum

\section{B. Seed protein electrophoresis}

The banding patterns of the investigated taxa are shown in Fig. 2A. A total of 88 bands were scored in the electrophoretic profiles of seed proteins of these taxa. The similarity matrix among the taxa was given in Table 3 . The highest similarity (55.26\%) was recorded between the two Enterolobium species namely: E. contortisiliquum and E. cyclocarpum, followed by (53.49\%)

Egypt. J. Bot., Vol. 56, No. 1 (2016) 
similarity observed between Acacia tortilis and A. tortilis subsp. raddiana. However, the lowest similarity $(7.14 \%)$ was recorded between Acacia saligna and Albizia lebbeck followed by $(8.11 \%)$ similarity recorded between Acacia tortilis and Albizia lebbeck and also between Albizia lebbeck and Enterolobium cyclocarpum. The phenogram (Fig. 2B) resulted from the hierarchical cluster analysis of the seed protein profiles of the examined taxa illustrated that these taxa are splitting into six clusters including two groups (Fig. 2 B \& C).

Cluster 1, II, and VI representing one species each namely: Albizia julibrissin, Pithecellobium dulce and Acacia saligna respectively. Cluster III comprises Acacia tortilis, A. tortilis subsp. raddiana and A. nilotica. Cluster IV includes Faidherbia albida (= Acacia albida), Enterolobium contortisiliquum, and E. cyclocarpum. Cluster V involves two groups: group 1, including Prosopis farcta and $P$. juliflora, and group 2, including Albizia lebbeck, Leucaena leucocephala, Dichrostachys cinerea and Acacia farnesiana.

TABLE 3. Similarity matrix of seed protein profiles among the studied Mimosoideae

\begin{tabular}{|l|c|c|c|c|c|c|c|c|c|c|c|c|c|c|c|}
\hline Taxa* & $\mathbf{1}$ & $\mathbf{2}$ & $\mathbf{3}$ & $\mathbf{4}$ & $\mathbf{5}$ & $\mathbf{6}$ & $\mathbf{7}$ & $\mathbf{8}$ & $\mathbf{9}$ & $\mathbf{1 0}$ & $\mathbf{1 1}$ & $\mathbf{1 2}$ & $\mathbf{1 3}$ & $\mathbf{1 4}$ & $\mathbf{1 5}$ \\
\hline 1 & 100 & & & & & & & & & & & & & & \\
\hline 2 & 29.27 & 100 & & & & & & & & & & & & & \\
\hline 3 & 33.33 & 28.95 & 100 & & & & & & & & & & & & \\
\hline 4 & 37.21 & 23.08 & 37.50 & 100 & & & & & & & & & & & \\
\hline 5 & 42.86 & 34.09 & 51.16 & 53.49 & 100 & & & & & & & & & & \\
\hline 6 & 25.49 & 23.26 & 20.00 & 18.00 & 20.69 & 100 & & & & & & & & & \\
\hline 7 & 7.14 & 9.68 & 13.89 & 8.11 & 8.51 & 18.42 & 100 & & & & & & & & \\
\hline 8 & 17.07 & 19.35 & 15.79 & 13.16 & 17.39 & 20.00 & 16.00 & 100 & & & & & & & \\
\hline 9 & 23.08 & 20.45 & 30.43 & 22.92 & 29.63 & 30.61 & 12.50 & 17.07 & 100 & & & & & & \\
\hline 10 & 22.92 & 29.73 & 25.00 & 28.57 & 27.45 & 22.92 & 8.11 & 16.22 & 55.26 & 100 & & & & & \\
\hline 11 & 26.00 & 18.18 & 28.26 & 20.83 & 32.69 & 26.00 & 10.00 & 27.03 & 36.96 & 31.82 & 100 & & & & \\
\hline 12 & 24.53 & 17.02 & 26.53 & 22.00 & 24.14 & 22.22 & 27.03 & 19.05 & 24.53 & 27.08 & 36.84 & 100 & & & \\
\hline 13 & 19.57 & 25.72 & 21.43 & 19.05 & 24.49 & 14.58 & 9.09 & 30.00 & 37.50 & 42.86 & 28.57 & 26.67 & 100 & & \\
\hline 14 & 24.49 & 21.95 & 29.55 & 30.23 & 24.07 & 27.08 & 20.00 & 15.38 & 22.00 & 27.27 & 30.43 & 36.96 & 23.81 & 100 & \\
\hline 15 & 21.28 & 24.32 & 35.90 & 20.93 & 31.25 & 16.33 & 15.15 & 17.14 & 14.00 & 23.81 & 24.44 & 25.53 & 23.08 & 31.71 & 100 \\
\hline
\end{tabular}

Taxa* are numbered as in Table (1). 


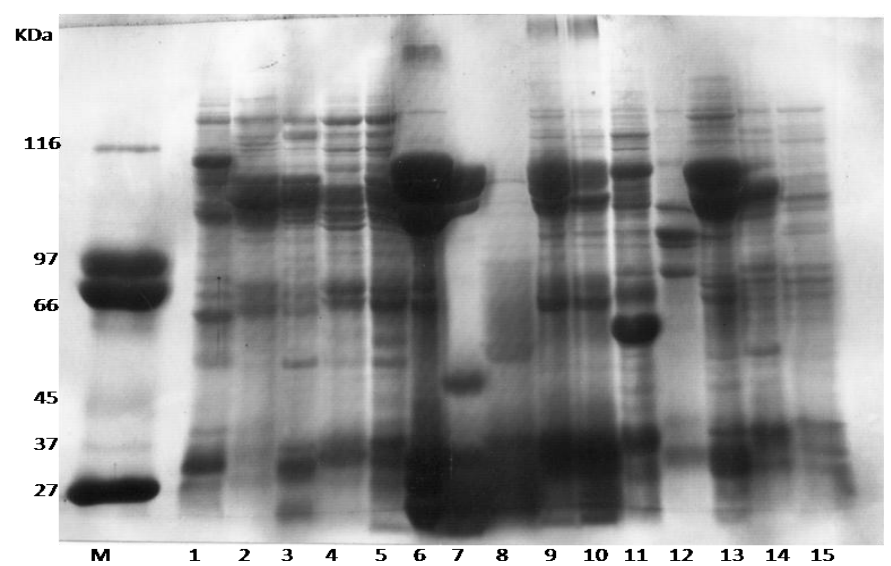

Fig. 2A. Variation in SDS-PAGE profile of seed proteins among the taxa studied. 1. Acacia saligna; 2. A. farnesiana; 3. A. nilotica; 4. A. tortilis subsp. raddiana; 5. A. tortilis; 6. Albizia julibrissin; 7. A. lebbeck; 8. Dichrostachys cinerea; 9. Enterolobium contortisiliquum; 10. E. cyclocarpum; 11. Faidherbia albida; 12. Pithecellobium dulce; 13. Leucaena leucocephala; 14. Prosopis farcta; 15. P. juliflora; $\mathrm{M}=$ Protein marker.

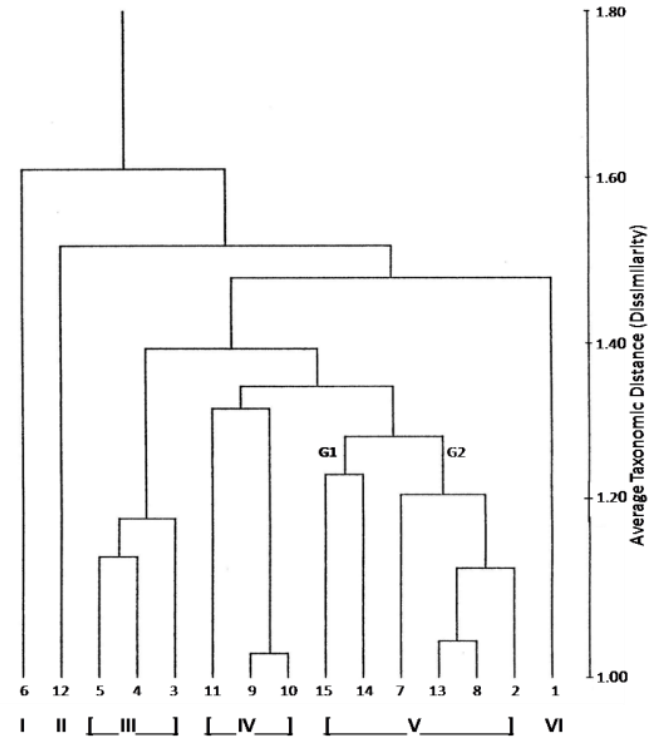

Fig. 2B. Phenogram based on the SDS-PAGE of seed protein characters illustrating average taxonomic distance (Dissimilarity) among the taxa studied. 1. Acacia saligna; 2. A. farnesiana; 3. A. nilotica; 4. A. tortilis subsp. raddiana; 5. A. tortilis; 6. Albizia julibrissin; 7. A. lebbeck; 8. Dichrostachys cinerea; 9. Enterolobium contortisiliquum; 10. E. cyclocarpum; 11. Faidherbia albida; 12. Pithecellobium dulce; 13. Leucaena leucocephala; 14. Prosopis farcta; 15. $P$. juliflora; G1=Group1; G2=Group2.

Egypt. J. Bot., Vol. 56, No. 1 (2016) 
Albizia julibrissin presented a considerable difference in its testa sculpture from A. lebbeck. This difference may support its clustering alone in Cluster I away from $A$. lebbeck based on its seed protein electrophoretic profile. According to Vassal (1972) and Pedley (1978) Acacia saligna has been placed in subgenus Phyllodineae (Syn. Subgenus Heterophyllum) while the other studied species of genus Acacia were classified in subgenus Acacia. A. saligna is actually with leaf-like petioles called phyllodes (Tiedeman and Johnson, 1992) while the other investigated Acacia species are with bipinnate leaves (Karakish, 2013). Moreover, Seeds of Acacia saligna exhibited a glossy dark brown colour and faint irregularly tuberculate testa which are not observed in any of the studied Acacia species. Hence, the separation of A. saligna in a separate cluster alone based on its seed protein profile can be justified.

According to Vassal (1972) both of Acacia tortilis and A. nilotica belong to the subgenus Acacia. Thus, the clustering of A. tortilis and A. tortilis subsp. raddiana with $A$. nilotica together, in Cluster III, may conform to this closeness. The degree of dissimilarity of Faidherbia albida (= Acacia albida) from the two studied Enterolobium species, Cluster IV, is insufficient for its further splitting but it is delimited as a different identity. Guinet (1969) referred that Acacia albida appeared sufficiently distinct in its pollen characters to warrant generic status. Vassal (1981) added that the unusual features of Acacia albida warrant the exclusion of the species from genus Acacia and its inclusion in the genus Faidherbia. Bentham (1875) was the first to restrict the tribe Acacieae to the genus Acacia but Vasal (1981) pointed out that it seems more appropriate to put the monotypic genus Faidherbia in the tribe Acacieae. However, Elias (1981) mentioned that Faidherbia albida (based on Acacia albida) is better transferred to tribe Ingeae and it may link the Ingeae with the Acacieae. Thus, the inclusion of Faidherbia albida with the two studied species of Enterolobium included in tribe Ingeae as listed by Nielsen (1981), in Cluster IV, may support the opinion of Elias (1981). In addition, the clustering of Enterolobium contortisiliquum and E. cyclocarpum at high degree of similarity may support the reliability of seed protein profiles for delimitation at the generic level. Similar observations were also recorded in members of Leguminosae by Hussein and George (2002) on some species representing genera of tribe Vicieae.

In Cluster V the three genera: Prosopis, Leucaena and Dichrostachys are included in the tribe Mimoseae (Lewis and Elias, 1981); but Acacia belongs to the tribe Acacieae (Vassal, 1981) and Albizia involved in tribe Ingeae (Nielsen, 1981). The inclusion of Albizia lebbeck with Leucanea leucocephala, Dichrostachys cinerea and Acacia farnesiana in Cluster V; group 2 may refer to the phyletic position of tribe Acacieae which is always considered a link between Mimoseae and Ingeae (Karakish et al., 2013). 


\section{Conclusion}

In this study, the variation in some macro-morphological seed features viz. seed shape, areole shape and colour of seed as well as peculiarities of the testa sculpturing patterns can be useful in delimitation and identification of the taxa studied. In addition, the phenogram produced from the numerical analysis of the obtained characters from SDS-PAGE profiles of seed protein supported some of the taxonomic considerations of some members from the MimosoideaeLeguminosae.

\section{References}

Abou-El-Enain, M. M., Loutfy, M. H. A. and Shehata, A. A. (2007) Seed surface characters and their systematic significance in the genus Lathyrus (Leguminosae, Papilionoideae, Vicieae). Feddes Repert., 118: 269-285.

Al-Gohary, I. and Mohamed, A. H. (2007). Seed morphology of Acacia in Egypt and its taxonomic significance. Int. J. Agri. Biol., 9: 435-438.

Arslan, E. and Ertugrul, K. (2010) Genetic relationships of the genera Onobrychis, Hedysarum and Sartoria using seed storage proteins. Turk. J. Biol., 34: 67-73.

Atoyebi, O.J, Faluyi, J. O. and Oyedapo, O. O. (2014) Investigation of the genetic diversity of selected wild and cultivated Sorghum germplasm using sodium dodecyl sulphate polyacrylamide gel electrophoresis. Greener J. Biol. Sci., 4:1-8.

Badr, A. (1995). Electrophoretic studies in relation to chromosomal criteria and the relationships of some taxa of Trifolium. Taxon, 44: 13-191.

Bentham, G. (1875) Revision of the suborder Mimoseae. Trans. Linn. Soc., London 30: $335-664$.

Boulos, L. (1999) "Flora of Egypt". Vol. I (Azollaceae-Oxalidaceae). Al Hadara Publishing, Cairo, Egypt, pp. 362-372.

Burghardt A.D. and Espert S. M. (2007) Phylogeny of Prosopis (Leguminosae) as shown by morphological and biochemical evidence. Aust. Syst. Bot., 20: 332-339.

Burkart, A. (1939) Mimozyganthus, nuevo genero de Leguminosae. Darwiniana, 3: 445454.

Chaung, T.I. and Heckard, L.R. (1983) Systematic significance of seed surface features in Orthocarpus (Scrophulariaceae, Subtribe Castillejinae). Amer. J. Bot., 70: 877-890.

Elias, T.S. (1981) Mimosoideae. In: "Advances in Legume Systematics". Polhill, R. M. and Raven, P. H. (Eds.) Vol. 2. Part 1, pp. 143-151. Int. Legume Conf. Proc. 24-29 July, 1978, Kew, England.

George N.M., Ghareeb A., Fawzi N.M. and Said S. (2013) Electrophoretic pattern of seed proteins in Trifolium L. and its taxonomic implications. Bangladesh J. Plant Taxon., 20: 19-26.

Egypt. J. Bot., Vol. 56, No. 1 (2016) 
Ghareeb, A., Khalifa, S. F. and Nael, F. (1999) Molecular systematics of some Cassia species. Cytologia, 64: 11-16.

Guinet, P. (1969) Les Mimosacees, etude de palynologie fondamentale, correlations, evolution. Trav. Sec. Sci. Techn. Pondichery, 9: 1-293.

Gunes, F. (2012) Seed morphology and their systematic importance of Lathyrus taxa belonging to Platystylis (= Lathyrostylis) section (Fabaceae) from Turkey. Afr. J. Agric. Res., 7: 265-277.

Gunn, C. R. (1981) Seed topography in the Fabaceae. Seed Sci. Technol., 9: 737-757.

Hussein, H.A. and George, N.M. (2002) Taxonomic importance of floral morphology, chromosome number and seed protein electorphoretic patterns in some species of tribe Vicieae (sub family: Papilionoideae-Leguminosae). Egypt. J. Biotechnol., 11: 106123.

Hussein, H.A., George, N. M., Ghareeb, A. and El-Demerdash, M.M. (2012) Diversity in micropyle, hilum and lens characteristics in seeds of the MimosoideaeLeguminosae. Proc. $7^{\text {th }}$ Int. Con. Biol. Sci. (Bot.), pp. 39-46. 5-6 December, Tanta Univ., Egypt.

Hussein, H.A. Khalifa, S.F.. Ghareeb, A. and Nael, F. (2002a) Taxonomic importance of seed characteristics of some species of Cassia and Senna (Subfamily: Caesalpinioideae-Leguminosae). Egypt. J. Biotechnol., 12: 248-265.

Hussein, H.A., Khalifa, S.F., Ghareeb, A. and Nael, F. (2002b) Taxonomic criteria of the characteristic features in seeds of some selected species of CaesalpinioideaeLeguminosae. Egypt. J. Biotechnol. 12: 280-298.

Hutchinson, J. (1964) "The Genera of Flowering Plants". Vol. I. Oxford Univ. Press, Oxford, England. 516 pp.

Karakish, E. A.; Moawed, M. M. and Tantawy, M. E. (2013) Seed morphology and protein patterns (SDS-PAGE) as a mean in classification of some taxa of the subfamily Mimosoideae (Fabaceae). Annual Review \& Research in Biology, 3: 367388.

Lersten, N. R. (1981) Testa topography in Leguminosae, subfamily Papilionoideae. Proc Iowa Acad. Sci., 88: 180-191.

Lersten, N.R. and Gunn, C. R. (1982) Testa characters in tribe Vicieae, with notes about tribes Abreae, Cicereae and Trifolieae (Fabaceae). U. S. Dep. Agric. Tech. Bull., 1667: $1-40$.

Lewis, G.P. and Elias, T.S. (1981) Mimoseae Bronn. In: Advances in Legume Systematics. Polhill, R.M. and Raven, P.H. (Eds.) Vol. 2, Part 1, pp. 155- 168. Int. Legume Conf. Proc. 24-29 July, 1978, Kew, England.

Manning, J. C. and Van Staden, J. (1987) The systematic significance of the testa anatomy in the Leguminosae: An illustrated survey. S. Afr. J. Bot., 53: 210-230. 
Nielsen, I. (1981) Ingeae Benth. In: Advances in Legume Systematics. Polhill, R. M. and Raven, P. H. (Eds.) Vol. 2, Part 1, pp. 173-190. Int. Legume Conf. Proc. 24-29 July, 1978, Kew, England.

Ommonhinmin, C. A. and Ogunbodede, O. O. (2013) Genetic diversity, taxonomy and legumins implications of seed storage protein profiling in Fabaceae. Afr. $J$. Biotechnol. 12: 2157-2163.

Pedley, L. (1978) A revision of Acacia Mill. in Queensland. Austrobaileya, 1: 75-234.

Polhill, R.M. and Raven, P.H. (1981) "Advances in Legume Systematics". Polhill, R.M. and Raven, P.H. (Eds.) Vol. 2, Part 1, pp. 155-190. Int. Legume Conf. Proc. 24-29 July, 1978, Kew, England.

Polhill, R.M.; Raven, P. H. and Stirton, C. H. (1981) Evolution and systematics of the Leguminosae. In: “Advances in Legume Systematics. Polhill”, R. M. and Raven, P. H. (Eds.) Vol. 2, Part 1, pp. 1- 26. Int. Legume Conf. Proc. 24-29 July, 1978, Kew, England.

Rholf, F. J. (1988) NTSYS-pc-numerical taxonomy and multivariate analysis New York.

Stearn, W. T. (1983) “Botanical Latin" $3^{\text {rd }}$ ed. Rev. David \& Charles Inc., USA, pp.506507.

Stevens, P. F. (2001) Angiosperm Phylogeny Website. Version 12, July 2012 and more or less continuously updated since." will do. http://www.mobot.org/MOBOT/ research/ APweb/ Accessed 20/12/2014.

Taia, W. K. (2004) Tribe Trifolieae: evidence from seed characters. Pak. J. Biol. Sci., 7: 1287-1302.

Tiedeman, J.A. and Johansen, D.E. (1992) Acacia cyanophylla for forage and fuel wood in north Africa. Agrofor. Syst., 7: 169-180.

Vassal, J. (1972) Apport des recherches ontogeniques et seminologiques a l'etude morphologique, taxonomique et phyllogenique du genre Acacia. Bull. Soc. Hist. Nat. Toulose, 108: 125-247.

Vassal, J. (1981) Acacieae Benth. In: "Advances in Legume Systematics". Polhill, R.M. and Raven, P.H. (Eds.) Vol. 2, Part L, PP. 169-171. Int. Legume Conf. Proc. 24-29 July, 1978, Kew, England. 
TAXONOMIC IMPLICATIONS OF SEED MORPHOLOGY AND ...

$$
\begin{aligned}
& \text { المدلولات التصنيفية لمورفولوجية البذرة والتفريد الكهربى }
\end{aligned}
$$

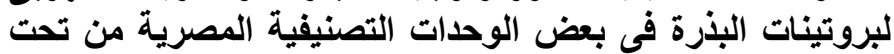

$$
\begin{aligned}
& \text { الفصيلة الطلحية ـ الفصيلة القرنية. } \\
& \text { نيللى ميشيل جورج - حسين عبدالباسط حسين ـ أحمد غريبـ مروة محسن المرداش }
\end{aligned}
$$

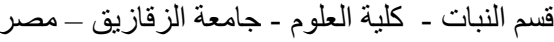

يتناول البحث دراسة بذور أربعة عشرة نوعا ووحدة تصنيفية واحدة من تحت

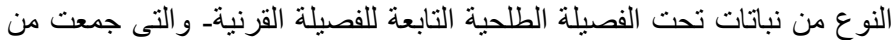

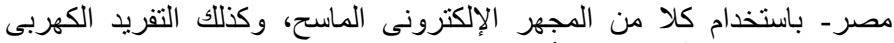

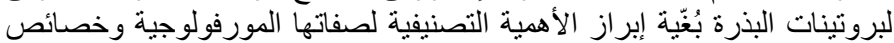

طرز البروتين بها.

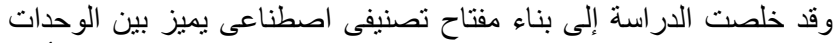

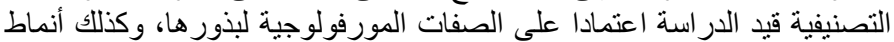

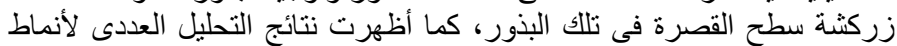

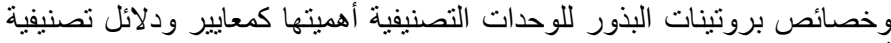
أمكنت من مناقثة بعض الآراء التصنيفية التى تخص الحالة التصنيفية للوحدات 